\title{
AWARENESS TOWARDS COVID-19 PANDEMIC AMONG FARM WOMEN AND ITS TECHNOLOGICAL STRATEGIES
}

\author{
NEHA SINGH ${ }^{1}$, POOJA SINGH ${ }^{2}$, MANU PATEL ${ }^{3} \&$ SAGAR SINGH $^{4}$ \\ ${ }^{I}$ Scholar, Department of EECM, CHSc, SKRAU, Bikaner, Rajasthan, India \\ ${ }^{2}$ Stduent, COA, CSA Kanpur, Uttar Pradesh, India \\ ${ }^{3}$ Student, Department of Seed Tech., B.U. Jhansi, Uttar Pradesh, India \\ ${ }^{4}$ Student, Department of M.E. N.I.T. Hamirpur, Himachal Pradesh, India
}

\begin{abstract}
Coronavirus disease (COVID-19) is an infectious disease caused by a newly discovered coronavirus. The virus responsible for this disease is severe acute respiratory syndrome coronavirus 2 (SARS-CoV-2).The present study was undertaken to study the awareness of farm women towards COVID-19 and also to suggest technological strategies to combat COVID-19 based on review. For study purpose, Jhansi block of Jhansi district (Uttar Pradesh) has been purposively selected. Two villages namely; Simarddha and Lakara of the Jhansi block have been selected through lottery method of sampling. Sample size of 100 farm women was selected. Data was collected through a structured interview schedule. The findings revealed the overall awareness index of farm women towards COVID-19 was 42.53i.e. to the extent of $42.53 \%$. It was concluded that more than half (53\%) of the farm women had overall low awareness level. Out of nine items of constraints faced by the farm women towards COVID-19, respondents had assigned first rank to lack of vegetable and crop selling and lack of regular income with mean 0.94.Awareness programme related to COVID -19 should be organized at village level with the help of local government officials. Various extension methods could be useful for spreading awareness such as nukkadnatak, puppet show, flash cards, flip charts, documentary on COVID-19 situation in India. The COVID-19 pandemic gave a lesson to us for the future alertness related to disaster management whether it is pandemic or epidemic, be prepared in advance against the pandemic at an individual and collective level.

KEYWORDS: COVID-19, Farm Women, Extension, Technology \& Awareness
\end{abstract}

Received: Jul 05, 2020; Accepted: Jul 25, 2020; Published: Aug 10, 2020; Paper Id.: IJASRAUG202020

\section{INTRODUCTION}

Coronavirus disease (COVID-19) is an infectious disease caused by a newly discovered coronavirus. The virus responsible for this disease is severe acute respiratory syndrome coronavirus 2 (SARS-CoV-2). Coronaviruses (CoV) are a large family of viruses that cause illness ranging from the common cold to more severe diseases. A novel coronavirus $(\mathrm{nCoV})$ is a new strain that has not been previously identified in humans (WHO).

The ongoing health crisis around COVID19 has affected all walks of life. Protecting lives of people suffering from the disease as well as frontline health responders have been the priority of nations. Governments have swung into actions since the Corona virus attack created an unprecedented situation. India declared a three-week nationwide lockdown till mid-April in the initial phase, which was subsequently extended for achieving satisfactory containment of the virus spread (ICRISAT, 2020). 
The various sectors had been severely affected during pandemic but agriculture sectorhad affected worst. Farm women were facing lots of hurdles. At village level, awareness towards COVID-19 is necessary to know because farm women are the key pillars of agriculture sector. As most of the research studies have shown that farm women are contributing to agriculture activities equal to men or sometimes more than men. The present study has been done on following objectives:

- To know the awareness of farm women towards COVID-19

- To suggest technological strategies to combat COVID-19 based on review

\section{METHODOLOGY}

For study purpose, Jhansi block of Jhansi district (Uttar Pradesh) has been purposively selected. Two villages namely; Simarddha and Lakara of the Jhansi block have been selected through lottery method of sampling. Fifty farm women from each village have been selected through simple random sampling. Thus, sample size of 100 farm women was selected for the study purpose. Data was collected through a structured interview schedule to collect awareness related data. Data was analyzed through using suitable statistical tools such as frequency, percentage, mean, standard deviation. The technological strategies to combat COVID-19 were discussed in this paper were based on reviews.

\section{RESULTS AND DISCUSSIONS}

Distribution of respondents according to their age is shown in table 1 . More than half (61\%) of the farm women belonged to middle age ( 36 - 55 years) group followed by, 26 percent of farm women belonged to young age group and very less i.e. 13 per cent of farm women belonged to old age group.

Table 1: Distribution of Respondents According to their Age (n=100)

\begin{tabular}{|c|l|c|}
\hline S. No. & \multicolumn{1}{|c|}{ Age } & Percentage \\
\hline 1 & Young age(18 - 35 years) & $26 \%$ \\
\hline 2 & Middle age(36 - 55 years) & $61 \%$ \\
\hline 3 & Old age(> 56 years) & $13 \%$ \\
\hline
\end{tabular}

It can be observed from Table 2 that near majority of respondents (68\%) belonged to SC/ST caste followed by, 22 per cent of respondents belonged to other backward caste and only 10 per cent of farm women belonged to general caste.

Table 2: Distribution of Respondents According to their Caste $(n=100)$

\begin{tabular}{|c|l|c|}
\hline S. No. & \multicolumn{1}{|c|}{ Caste } & Percentage \\
\hline 1 & SC/ST & $68 \%$ \\
\hline 2 & Other backward caste & $22 \%$ \\
\hline 3 & General & $10 \%$ \\
\hline
\end{tabular}

It was revealed from table 3 that more than half (59\%) of the farm women were illiterate followed by, 20 per cent of farm women were completed their education up to primary (1-5) only, farm women (12\%) completed their high school education and 9 per cent of farm women had completed their education up to intermediate. 


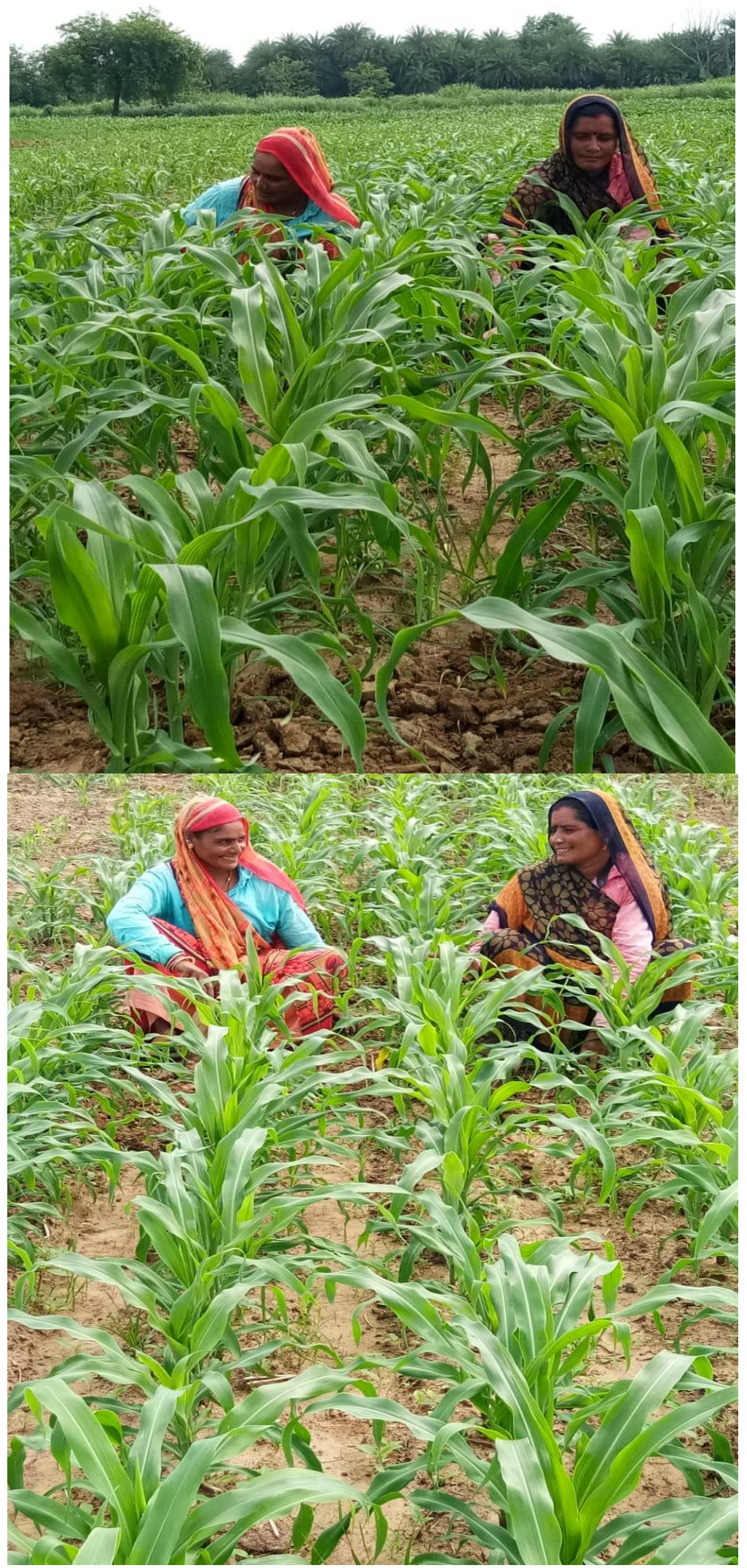

Plate 1: Farm Women Working in Sorghum (Jowar) Fields. 
Table 3: Distribution of Respondents According to their Education $(\mathbf{n}=100)$

\begin{tabular}{|c|l|c|}
\hline S.No. & \multicolumn{1}{|c|}{ Education } & Percentage \\
\hline 1 & Illiterate (0) & $59 \%$ \\
\hline 2 & Primary (1-5) & $20 \%$ \\
\hline 3 & High school (10) & $12 \%$ \\
\hline 4 & Intermediate(12) & $9 \%$ \\
\hline
\end{tabular}

It was reported from the findings of table 4 that most of the farm women $(80 \%)$ were having medium (5-8 members ) family size followed by, 14 per cent of the farm women had large (>8 members) family size and very least (6\%) of the farm women had small (1-4 members) family size.

Table 4: Distribution of Respondents According to their Family Size $(\mathbf{n}=\mathbf{1 0 0})$

\begin{tabular}{|c|l|c|}
\hline S.No. & \multicolumn{1}{|c|}{ Family size } & Percentage \\
\hline 1 & Small(1-4 members) & $14 \%$ \\
\hline 2 & Medium (5-8 members) & $80 \%$ \\
\hline 3 & Large(> 8 members $)$ & $6 \%$ \\
\hline
\end{tabular}

It is apparent from the table 5 that most of the respondents (90\%) belonged to joint family type followed by; only 10 per cent of respondents were belonged to nuclear family type.

Table 5: Distribution of Respondents According to their Family Type (n=100)

\begin{tabular}{|c|l|c|}
\hline S.No. & \multicolumn{1}{|c|}{ Family Type } & Percentage \\
\hline 1 & Nuclear family & $10 \%$ \\
\hline 2 & Joint family & $90 \%$ \\
\hline
\end{tabular}

Table 6: Distribution of Respondents According to their Family Occupation $(n=100)$

\begin{tabular}{|c|l|c|}
\hline S.No. & \multicolumn{1}{|c|}{ Family Occupation } & Percentage \\
\hline 1 & Agriculture Labourer & $25 \%$ \\
\hline 2 & Agriculture & $75 \%$ \\
\hline 3 & Business & 0 \\
\hline 4 & Salaried Job & 0 \\
\hline
\end{tabular}

The data revealed from the table 6 that majority of the respondents $(75 \%)$ had agriculture as their major family occupation followed by, 25 per cent of the farm women working as agriculture labourer.

Table 7: Distribution of Respondents According to their Family Land Holding (n=100)

\begin{tabular}{|c|l|c|}
\hline S. No. & \multicolumn{1}{|c|}{ Family Land Holding } & Percentage \\
\hline 1 & Landless & $36.90 \%$ \\
\hline 2 & Small(<1 ha) & $45.60 \%$ \\
\hline 3 & Marginal(1 ha $-2 \mathrm{ha})$ & $15 \%$ \\
\hline 4 & Large( $>2 \mathrm{ha})$ & $2.50 \%$ \\
\hline
\end{tabular}

It can be find out from the table 7 that less than half $(45.60 \%)$ of the farm women had small size $(<1$ ha) land holding followed by, 36.90 percent of the farm women are landless, farm women having marginal (1 ha-2 ha) family land holding and very least $2.50 \%$ of the farm women had large (> 2 ha) family land holding.

Near majority of the farm women (67\%) from Table 8, had annual family income of Rs. 1,20,000- Rs.1,50,000 . Followed by, 18 percent of the farm women had annual family income of Rs. 90,000- Rs. 1,20,000, farm women (9\%) had annual family income Less than Rs.90,000 and very least of the farm women (6\%) had annual family income more than Rs. $1,50,000$. 
Table 8: Distribution of Respondents According to their Annual Family Income (n=100)

\begin{tabular}{|c|l|c|}
\hline S. No. & \multicolumn{1}{|c|}{ Annual Family Income } & Percentage \\
\hline 1 & Less than Rs.90,000 & $9 \%$ \\
\hline 2 & Rs. 90,000- Rs. 1,20,000 & $18 \%$ \\
\hline 3 & Rs. 1,20,000- Rs.1,50,000 & $67 \%$ \\
\hline 4 & More than Rs. $1,50,000$ & $6 \%$ \\
\hline
\end{tabular}

The data revealed from the table 9 that most of the respondents (80\%) were married followed by, 20 per cent of the farm women were unmarried.

Table 9: Distribution of Respondents According to their Marital Status ( $n=100)$

\begin{tabular}{|c|l|c|}
\hline S. No. & \multicolumn{1}{|c|}{ Marital Status } & Percentage \\
\hline 1 & Married & $80 \%$ \\
\hline 2 & Unmarried & $20 \%$ \\
\hline
\end{tabular}

Awareness of farm women towards Covid-19 had depicted in table 10. It was revealed from the data that most of the farm women (83\%) wash their vegetables when they bought from the market. Followed by, majority of the (75\%) farm women wear mask while interacting with people, presence of corona patient in their locality (69\%), following the social distancing norms (50\%), sanitizing hands frequently (48\%), taking something for boosting immunity on daily basis (45\%), aaroygasetu app in mobile (35\%), you and your locality have been tested for covid 19 (32\%), using alcohol-based sanitizer $(30 \%)$, aware about covid 19 helpline number in your area $(28 \%)$, covid 19 is a pandemic disease and regular visits of medical staff (25\%) and full form of covid 19 (8\%). Overall awareness index was 42.53 which means awareness towards COVID-19 is to the extent of $42.53 \%$. which is less than half.

Table 10: Awareness of Farm Women Towards Covid-19 (n=100)

\begin{tabular}{|c|l|c|}
\hline S. No. & \multicolumn{1}{|c|}{ Awareness Statement } & Percentage \\
\hline 1 & Do you know the full form of covid19 ? & $08 \%$ \\
\hline 2 & Do you know covid 19 is a pandemic disease? & $25 \%$ \\
\hline 3 & Do you sanitize your hands frequently? & $48 \%$ \\
\hline 4 & Do you follow the social distancing norms ? & $50 \%$ \\
\hline 5 & Do you take something for boosting your immunity on daily basis ? & $45 \%$ \\
\hline 6 & Do you have aaroygasetu app in your mobile ? & $35 \%$ \\
\hline 7 & Do you aware about covid 19 helpline number in your area ? & $28 \%$ \\
\hline 8 & Do you wear mask while interacting with people ? & $75 \%$ \\
\hline 9 & Do you wash your vegetables when you bought from the market ? & $83 \%$ \\
\hline 10 & Is there any corona patient in your locality? & $69 \%$ \\
\hline 11 & Does you and your locality have been tested for covid19 ? & $32 \%$ \\
\hline 12 & Is there regular visits of medical staff & $25 \%$ \\
\hline 13 & Do you use alcohol-based sanitizer? & $30 \%$ \\
\hline & $\quad$ Overall Awareness Index & $\mathbf{4 2 . 5 3}$ \\
\hline
\end{tabular}

Table 11: Overall Awareness Level of Farm Women towards Covid-19 ( $\mathbf{n = 1 0 0 )}$

\begin{tabular}{|c|l|c|c|}
\hline S. No. & Awareness level & Score Range & Percentage \\
\hline 1 & Low & $<=3$ & $53 \%$ \\
\hline 2 & Medium & 4 to 5 & $31 \%$ \\
\hline 3 & High & $>=6$ & $16 \%$ \\
\hline
\end{tabular}

The overall awareness level of farm women towards COVID -19 was presented in table 13. It was concluded that more than half $(53 \%)$ of the farm women had overall low awareness level. Followed by, 31 per cent of farm women had medium level of awareness and only 16 per cent of farm women had high level of awareness. 
Table 12: Constraints Faced by Farm Women towards Covid-19 (n=100)

\begin{tabular}{|c|l|c|c|c|c|}
\hline S. No. & \multicolumn{1}{|c|}{ Constraints } & Mean & S.D. & Percentage & Rank \\
\hline 1 & Lack of agricultural inputs (seed, fertilizer, equipment etc.) & 0.9 & 0.30 & $90 \%$ & II \\
\hline 2 & Sudden price hike & 0.71 & 0.45 & $71 \%$ & VII \\
\hline 3 & Lack of vegetable and crop selling & 0.94 & 0.23 & $94 \%$ & I \\
\hline 4 & Improper decision making & 0.64 & 0.48 & $64 \%$ & VIII \\
\hline 5 & Lack of marketing facility & 0.81 & 0.39 & $81 \%$ & V \\
\hline 6 & Lack of regular income & 0.94 & 0.23 & $94 \%$ & I \\
\hline 7 & Lack of transport facility & 0.89 & 0.31 & $89 \%$ & III \\
\hline 8 & Lack of proper source of information & 0.8 & 0.40 & $80 \%$ & VI \\
\hline 9 & Workload & 0.84 & 0.36 & $84 \%$ & IV \\
\hline
\end{tabular}

The data presented in Table 14 revealed that out of nine items of constraints faced by the farm women towards COVID-19, respondents had assigned first rank to lack of vegetable and crop selling and lack of regular income with mean 0.94 .

Lack of agricultural inputs (seed, fertilizer, equipment etc.) assigned II rank by the respondents with mean 0.9. The constraints lack of transport facility (III rank), workload (IV rank), lack of marketing facility (V rank), lack of proper source of information (VI rank), sudden price hike (VII rank) and improper decision making (VIII rank) were pointed out by the respondents of the study.

\section{TECHNOLOGICAL STRATEGIES TO COMBAT COVID-19}

\section{Satellite Monitoring}

While dozens of makeshift hospitals were being constructed at breakneck pace, their progress can be continuously monitored by satellite monitoring systems. A health visualization of COVID-19 can be created on which people could see the geographical reach of the virus and could find out the distance between them and active infection.

\section{Robotics}

Little robots were used in several hospitals for preparing meals, spraying disinfectants, robots were on the frontline to prevent the spread of Coronavirus in various countries. In many hospitals, robots were also performing diagnosis and conducting thermal imaging. Thus, robotics technologies could also be used in our country a lot.

\section{Health Sensors and Apps}

AarogyaSetu app works on the principle of contact tracing and requires an individual to feed symptoms and his movement. Temperature screening by IR-Thermal sensors.

\section{Drones}

Agricultural drones could be helpful in spraying disinfectants and sanitizing in the countryside. In some of the severely affected areas, where humans were at a risk of catching the virus, drones came to the rescue. Drones were transporting both medical equipment and patient samples, saving time and enhancing the speed of deliveries, while preventing contamination of medical samples.

\section{Face Recogniton}

Smartphone apps are also being used to keep a tab on people's movements and ascertain whether or not they have been in contact with an infected person. 
Face recognition and infrared temperature detection techniques shouldbe used to recognize people to even if they are masked, to keep a tab on people's movements and ascertain whether or not they have been in contact with an infected person

\section{Autonumous Vehicles}

At a time of severe crunch of healthcare professionals and the risk of people-to-people contact, autonomous vehicles can be seen as a great utility in delivering essential goods like medicines and food items.

\section{CONCLUSIONS}

Thus, it can be concluded that awareness towards COVID-19 pandemic among farm women is low. Awareness programme related to COVID -19 should be organized at village level with the help of local government officials. Various extension methods could be useful for spreading awareness such as nukkadnatak, puppet show, flash cards, flip charts, documentary on COVID-19 situation in India. The COVID-19 pandemic gave a lesson to us for the future alertness related to disaster management whether it is pandemic or epidemic, be prepared in advance against the pandemic at an individual and collective level. What we actually need is preparedness. Though, these technological strategies is advanced and will take time to establish and functionally operated at ground level, India should think about emergence or dire need of technologies to combat such pandemic and further health emergencies in future.

\section{REFERENCES}

1. http://www.emro.who.int/health-topics/corona-virus/about-covid-19.html retrieved on dated 27-07-2020.

2. https://www.icrisat.org/containing-covid19-impacts-on-indian-agriculture/ retrieved on dated 28-07-2020.

3. https://www.geospatialworld.net/article/the-sino-approach-use-of-technology-to-combat-covid-19/retrieved on dated 29-072020.

4. https://cio.economictimes.indiatimes.com/news/next-gen-technologies/covid-19-8-ways-in-which-technology-helps-pandemicmanagement/75139759 retrieved on dated 30-07-2020.

5. Montano-Soto, Tatiana, Evarista Arellano-García, and L. Camarena-Ojinaga."Genotoxic biomonitoring and exposure to pesticides in women laborers at maneadero valley in Baja California, Mexico." International Journal of Applied and Natural Sciences 3.2 (2014): 89-96.

6. Chatterjee, Kousik, and sabuj dasgupta."Literature Review of Information Seeking Behavior of Farmers in India." International Journal of Humanities and Social Sciences (IJHSS) 5.5 (2016): 163-182.

7. Manshani, Sapna, and Anjna Dubey. "Startup Women in Startup India: A Study Of Women Entrepreneurs in India." International Journal of Business Management (IJBGM), 91100 (2017). 
